\title{
Glycans as Key Checkpoints of T Cell Activity and Function
}

\author{
Márcia S. Pereira $1,2,3 \dagger$, Inês Alves ${ }^{1,2,4 \dagger}$, Manuel Vicente ${ }^{1,2,3}$, Ana Campar ${ }^{1,2,3,5}$, \\ Mariana C. Silva ${ }^{1,2}$, Nuno A. Padrão ${ }^{1,2,4}$, Vanda Pinto ${ }^{1,2}$, Ângela Fernandes ${ }^{1,2}$, \\ Ana M. Dias ${ }^{1,2}$ and Salomé S. Pinho ${ }^{1,2,4 *}$ \\ ${ }^{1}$ Institute of Molecular Pathology and Immunology of the University of Porto (IPATIMUP), Porto, Portugal, ${ }^{2}$ Institute for \\ Research and Innovation in Health (I3S), Porto, Portugal, ${ }^{3}$ Institute of Biomedical Sciences of Abel Salazar, University of \\ Porto, Porto, Portugal, ${ }^{4}$ Medical Faculty, University of Porto, Porto, Portugal, ${ }^{5}$ Centro Hospitalar do Porto, Porto, Portugal
}

The immune system is highly controlled and fine-tuned by glycosylation, through the addition of a diversity of carbohydrates structures (glycans) to virtually all immune cell receptors. Despite a relative backlog in understanding the importance of glycans in the immune system, due to its inherent complexity, remarkable findings have been highlighting the essential contributions of glycosylation in the regulation of both innate and adaptive immune responses with important implications in the pathogenesis of major diseases such as autoimmunity and cancer. Glycans are implicated in fundamental cellular and molecular processes that regulate both stimulatory and inhibitory immune pathways. Besides being actively involved in pathogen recognition through interaction with glycan-binding proteins (such as C-type lectins), glycans have been also shown to regulate key pathophysiological steps within T cell biology such as $\mathrm{T}$ cell development and thymocyte selection; $T$ cell activity and signaling as well as $T$ cell differentiation and proliferation. These effects of glycans in T cells functions highlight their importance as determinants of either self-tolerance or $\mathrm{T}$ cell hyper-responsiveness which ultimately might be implicated in the creation of tolerogenic pathways in cancer or loss of immunological tolerance in autoimmunity. This review discusses how specific glycans (with a focus on $N$-linked glycans) act as regulators of $\mathrm{T}$ cell biology and their implications in disease.

Keywords: $\boldsymbol{N}$-glycosylation, glycans, $\mathrm{T}$ cells, immune response, autoimmunity, self-tolerance

\section{INTRODUCTION}

The immune system is highly regulated by a series of stimulatory and inhibitory pathways that are crucial to maintain a healthy and balanced system. Disruption of the control of this immunological balance can result in abnormal stimulatory signals associated with the loss of immune tolerance in autoimmunity or in the creation of aberrant immunosuppressive networks that occur in cancer. Accumulating evidences have been demonstrating the importance of glycans and glycans binding proteins [including galectins (1,2), C-type lectins (3), and sialic acid-binding immunoglobulin-type lectins (siglecs) $(4,5)]$ in the regulation of both innate and adaptive immune responses. In fact, all cells are covered with a dense coat of glycans that constitute a major molecular interface between cells and their environment. The diversity of glycans presentation at cell surface is enormous, encoding a myriad of important biological information that remains to be fully characterized. Glycosylation is the enzymatic process responsible for the attachment of glycans (carbohydrates) to 
proteins or lipids (predominantly via nitrogen $(N)$ and oxygen (O) linkages), a process that occurs in the Endoplasmic Reticulum/Golgi compartment of essentially all cells being mediated by the coordinated action of a portfolio of different glycosyltransferases and glycosidases enzymes (6). The proper development and function of the immune system relies both on the dynamic regulation of the expression of glycan-structures and glycan-binding proteins, and the interactions between them (7). This review discusses the role of glycans (with a focus on $N$-linked glycans) on $\mathrm{T}$ cells biology and function, including $\mathrm{T}$ cell development, activation, differentiation, and signaling. This dynamic interplay between glycans and $\mathrm{T}$ cells activity controlling both auto-reactivity and self-tolerance will be presented and discussed (Figure 1).

\section{GLYCANS IN T CELL DEVELOPMENT AND THYMUS SELECTION}

$\mathrm{T}$ cells are developed in the thymus where a microenvironment is set, which enables the selection of $\mathrm{T}$ cell receptors (TCRs) to generate a diverse repertoire of potential antigen recognition (8). Lymphoid progenitors from the bone marrow enter into the cortical tissue of the thymus, where they start to expand and develop $(9,10)$. Despite the fact that the role of glycosylation in $\mathrm{T}$ cell development and thymus selections still remains to be fully understood, some important findings highlight the relevance of glycans in this process (Figure 2).

\section{Role of Glycans in Thymus Seeding and T Cell Lineage Commitment}

The initial step of $\mathrm{T}$ cell development, the trafficking of thymus-seeding progenitors (TSPs) to the thymus, is an active process that relies on the expression of P-selectin in the thymic epithelium and its partner, P-selectin glycoprotein ligand-1 (PSGL-1), expressed by circulating TSPs-derived from the bone marrow (11). The expression and post-translational modifications of PSGL-1 are regulated in bone marrow progenitors. The deficiency of $\alpha 1,3$ fucosylation on PSGL-1, required for its binding to $\mathrm{P}$-selectin, was shown to be associated with the impairment of TSPs homing into the thymus (12). Once TSPs enter the thymus, they develop into early thymocyte progenitors (ETPs), a subset of the $\mathrm{CD} 4^{-} \mathrm{CD} 8^{-}$double negative 1 (DN1) population, which give rise to multiple lymphoid lineages (8). The conserved Notch signaling pathway is responsible for the commitment of DN1 thymocytes to the $\mathrm{T}$ cell lineage (13). The glycosylation profile of Notch receptors (and ligands) was shown to regulate Notch-dependent intracellular signal transduction. The lunatic, manic, and radical Fringe are the glycosyltransferases that modify Notch receptors by transferring $\mathrm{N}$-acetylglucosamine (GlcNAc) to $\mathrm{O}$-linked fucose glycans of epidermal growth factor-like (EGF-like) repeats, present in the extracellular domain of Notch, and described to regulate its cellsurface signaling and function $(14,15)$. Loss of the three Fringe glycosyltransferases leads to a reduced binding of Notch to Deltalike ligands (DLL), namely DLL4, altering the frequencies of several $\mathrm{T}$ cell subsets in the thymus (16). The first indication that Fringe-mediated Notch glycosylation was involved in T cell development was shown when the lunatic Fringe gene, Lfng, was misexpressed under a $l c k$-proximal promoter (17). This alteration of the Notch glycosylation profile (lack of GlcNAc in the EGF-like repeats) resulted in a large B cell population developed from lymphoid progenitors in the thymus. In fact, further work showed that $L f n g$ is poorly expressed in $\mathrm{CD} 4^{+} \mathrm{CD} 8^{+}$ double positive (DP) thymocytes, but when ectopically expressed in that population (under $l c k$-proximal promoter), led to an increased binding of Notch to its ligands on stromal cells, blocking DN development, and enabling B cell differentiation (18). These studies also revealed that changes in the glycosylation of Notch across $\mathrm{T}$ cell development also impacts on its signaling pathway. At DN stages, the reactions that drive development are dependent on Notch interactions with DLLs, which exist at functionally limiting concentrations. The high levels of $L f n g$ expression in DNs facilitate Notch interactions with DLLs and the dramatic downregulation of $L f n g$ in DPs coincides with Notch-independent reactions of $\mathrm{T}$ cell development. The final commitment to the T cell lineage occurs at the DN3 stage, where a recombination-activating genes (RAG)-mediated productive rearrangement of the Tcrb leads to the expression of the $B$ chain of the TCR (TCRß) and the formation of a pre-TCR signaling complex $(13,19)$.

\section{Role of Glycans in Thymocyte B Selection}

Together with Notch and Interleukin (IL)-7, the pre-TCR signaling initiates $ß$-selection, by inducing the downregulation of the RAG complex expression (Rag1 and Rag2) in quiescent DN3 (DN3a), becoming large cycling DN3 thymocytes (DN3b), which differentiate into DN4 cells. A deficient pre-TCR signaling in $l c k-$ null cells is rescued by Lfng overexpression, but not in a Rag2-/background, indicating a pre-TCR dependency for development (20). Upon B-selection, it was recently demonstrated that DN4 cells upregulate glucose and glutamine metabolites that enter into the hexosamine pathway, increasing the production of UDP-GlcNAc, which is needed to undergo clonal expansion $(8,21)$. The UDP-GlcNAc is also the substrate of the $O$ GlcNAc transferase (OGT) in the process of O-GlcNAcylation of intracellular proteins on serine and threonine residues (22). Recent evidences showed that $O$-GlcNAcylation regulates the process of T cell development (23). Using a conditional knockout mouse model of OGT in the DN stage, it was shown a reduced population of DPs, indicating either a deficiency on B-selection or in clonal expansion of DN4s. The absence of OGT appeared not to impact self-renewal of DNs, or their differentiation into DPs, but to promote the failure of the clonal expansion of DN4, in response to Notch ligands. A feedback mechanism was proposed in which the metabolic changes (the shift to glycolysis) that support the DN-to-DP stage of thymocyte differentiation, controlled by Notch, induces c-Myc expression, which in turn controls the rate of $\mathrm{T}$ cell nutrient uptake as well as the expression of OGT and consequently the abundance of $O$-GlcNAc (15). The $O$-GlcNAcylation of c-Myc was also shown to increase its stability (24), further contributing to the feedback loop.

In the stage of post- $\beta$ selected DN4 thymocytes, it was seen a 10 -fold increase in expression of ST6 $\beta$-Galactoside 


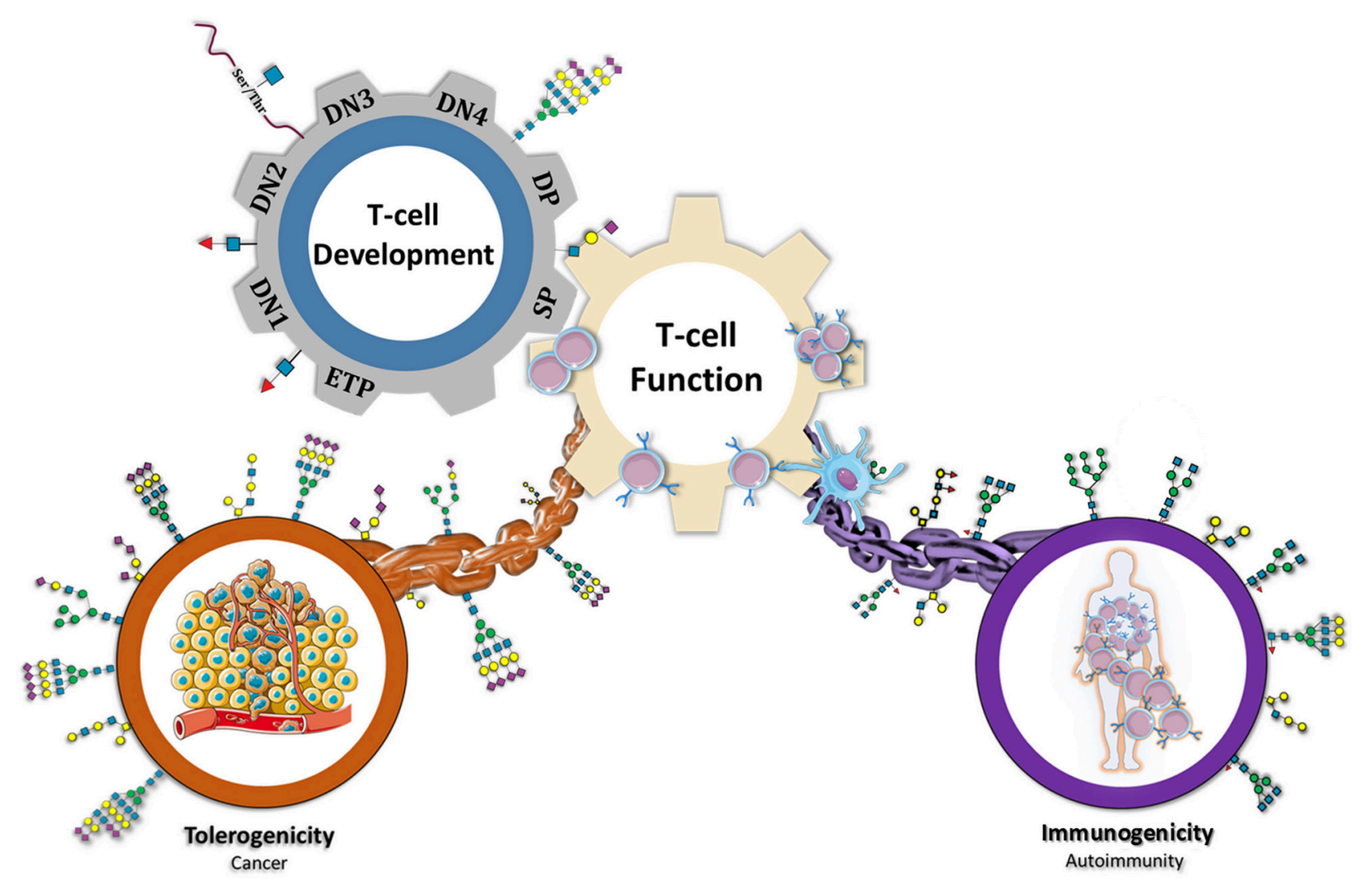

$\begin{array}{lll}\square N \text {-Acetylglucosamine } & O \text { Mannose } & \triangle \text { Fucose } \\ \square N \text {-Acetylgalactosamine } & O \text { Galactose } & \diamond \text { Sialic acid }\end{array}$

FIGURE 1 | Glycans as a major connective chain that controls T cell response in either a tolerogenic or immunostimulatory scenario. Glycosylation appears to be central in regulating several steps of a T cell's life. During T cell development, different population of T cells (ETP, early thymocyte progenitor; DN1, 2, 3, and 4, double negative; DP, double positive; SP, single positive) display specific glycosylation patterns. The normal glycosylation of SP population results in an educated T cell function. However, by genetic, environmental or metabolic constrains, T cell glycosylation can be compromised re-directing immune system toward an immunostimulatory or tolerogenic response. Glycans are proposed here as key players in immune-unbalanced diseases, such as autoimmunity and cancer.

a2,6-Sialyltransferase 1 (ST6Gal I) when comparing to the DN3 population, which resulted in an increase in $\alpha 2,6$-linked sialic acid (25). Accordingly, in ST6Gal1 deficient mice, the $\mathrm{DN}$ populations were decreased, beginning at the DN1 subset. Microarray data showed a downregulation of CD96 (receptor molecule of nectin-1, that plays a putative role in cell migration) in the DN2 and DN3 populations in the ST6Gal1 deficiency background, and a disruption of thymopoiesis in these mice was proposed. Moreover, ST3 $\beta$-Galactoside $\alpha 2,3$-Sialyltransferase 1 (ST3Gal I) expression is decreased in most DN and in all DP, only increasing in single-positive (SP) thymocytes (26). In ST3Gal1 ${ }^{-/-}$mice, the TCR repertoire was significantly altered, indicating a role for sialylation in thymocyte selection (27).

\section{Role of Glycans in Positive and Negative Selection in the Thymus}

The $B$-selected DN4 cells undergo rapid self-renewal, giving rise to a clonally expanded population, that differentiate into
DP $\mathrm{CD}^{+}{ }^{+} \mathrm{CD}^{+}{ }^{+}$thymocytes (8). In this developmental stage, mature TCR $\alpha \beta$ receptors are formed (28) and the expression of the co-receptors CD4 and CD8 confer a MHC class II and class I restriction of TCR activation, respectively. The newly formed mature TCRs are then screened by thymic epithelial cells (TECs) by the specificity and binding strength for the MHC ligands presented. The next developmental process is named positive selection, where the DP population is enriched for cells that express an immunocompetent $\operatorname{TCR}(8,29)$. The selected DPs then commit to the SP $\mathrm{CD}^{+}$or $\mathrm{CD}^{+}$lineage and go through a process called negative selection, which eliminates autoreactive T cells $(8,29)$. The affinity of the correctly assembled TCR $\alpha \beta$ for the MHC-antigen complexes determines cell survival and differentiation. Glycosylation modifications of the TCR may provide an alternative mechanism to control positive and negative selection by directly affecting the TCR-MHC-antigen binding, TCR interaction with its co-receptors and the threshold of activation (30), an issue that is far from being fully elucidated. 


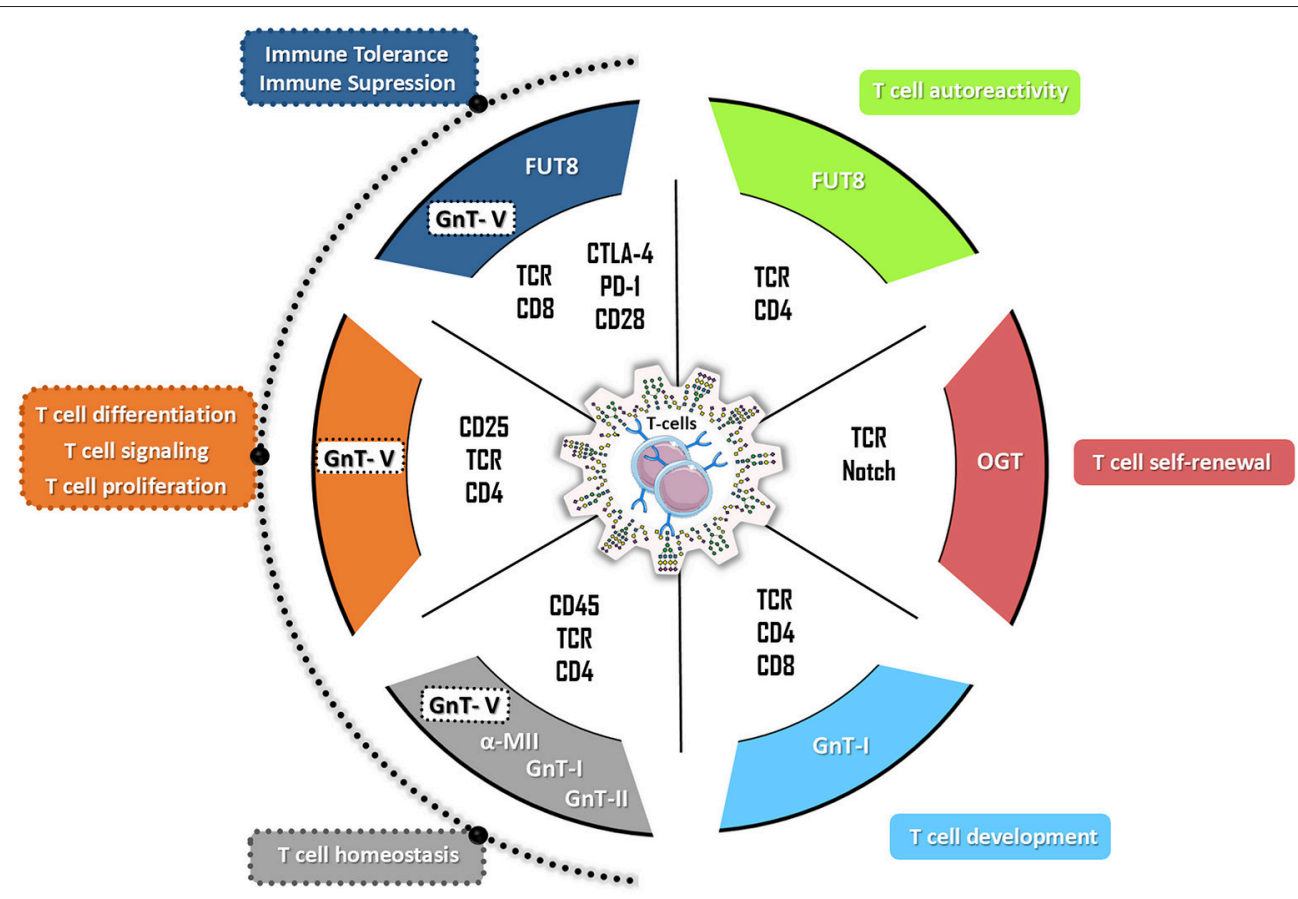

FIGURE 2 | The hallmarks of glycans in T cell biology. N-glycans have a broad effect on the multiple T cell functions with impact both in autoreactivity and in immune tolerance. Particularly, the complex branched $N$-glycans catalyzed by beta 1,6-N-acetylglucosaminyltransferase V (GnT-V) (encoded by MGAT5 gene) have been demonstrated to control different $T$ cells functions by targeting different $T$ cells receptors (such as TCR, CD25, and CD4) and therefore regulating $T$ cell proliferation, $T$ cell differentiation, T cell signaling as well as the production of inflammatory cytokines. Alterations on GnT-V activity but also in alpha-mannosidase II ( $\alpha$-MII) as well as in N-acetylglucosaminyltransferase I (GnT-I, MGAT1 gene) and II (GnT-II, MGAT2 gene) activity were shown to compromise T cell homeostasis being associated with the development of several autoimmune disorders in humans and mouse models (such as EAE, IBD, SLE, TID). The FUT8-mediated core fucosylation of TCR was associated with hyperactivation of CD4 ${ }^{+}$T cells (T cells autoreactivity) whereas the modification of the co-inhibitory receptors (CTLA-4 and PD-1) by FUT8-mediated core fucose results in immune tolerance. The T cell development and T cell self-renewal are controlled by GnT-I-mediated glycosylation and by O-GlcNAcylation through OGT (O-GlcNAc transferase), respectively.

The subunits of the TCR $\alpha \beta$ contain at least 7 potential sites for $N$-linked glycosylation and the TCR-CD3 complex is estimated to have $12 \mathrm{~N}$-glycan addition sites that contribute to TCR folding and functions $(31,32)$. Indeed, selective removal of conserved $N$ glycosylation sites of the constant regions of the TCR, enhanced its functional avidity (the sensitivity of the $\mathrm{T}$ cell response to other cell which carries the respective MHC-peptide) (32). However, whether $\mathrm{N}$-glycosylation in the variable regions of the TCR affect its selection remains to be addressed. Moreover, low levels of sialylation in DPs are associated with binding to Major Histocompatibility Complex (MHC) class I (common to all nucleated cells) and the increased expression of sialic-acid linkages on differentiated SP CD8 ${ }^{+}$thymic T cells was shown to decrease the binding avidity of CD8 for MHC class I molecules, which acts as a regulation for a TCR affinity dependent negative selection (33).

Furthermore the deficiency of the Mgat5 gene, that encodes for a Golgi branching enzyme $N$-acetylglucosaminyltransferase $\mathrm{V}$ (GnT-V) was shown to markedly increases TCR clustering and signaling at the immune synapse, resulting in a lower $\mathrm{T}$ cell activation threshold and increased incidence of autoimmune disease in vivo and in human (30). In a model of positive selection, it was demonstrated that branching $\mathrm{N}$-glycosylation dynamically expands the affinity spectrum of positive selection by differentially controlling both the lower and upper limits of positively selected TCR-MHC-antigen interactions (34). The intracellular domains of CD4 and CD8 co-receptors bind Lck, enhancing TCR responses to low-affinity MHC-antigen complexes when coupled to the TCR (35). Both co-receptors have $N$-glycosylation sites and it was shown that the branching deficiency in Mgat $^{\mathrm{f} / \mathrm{f}} \mathrm{Lck} \mathrm{Cre}{ }^{+} \mathrm{T}$ cells resulted in decreased surface expression of CD4 and CD8 receptors (34). The lack of branched $N$-glycans in the same genetic background also decreased TCR threshold signaling (30). These evidences supported that branching $N$-glycans display an important role in the maturation of DN cells and/or TCR selection.

Changes in the expression of $O$-linked glycans also impact $\mathrm{T}$ cell development by modulating galectin binding. Galectin-1 was shown to induce apoptosis of immature thymocytes through binding to core $2 \mathrm{O}$-glycans expressed in CD43 and CD45 (36). In contrast, $\mathrm{CD} 45$ on mature thymocytes bears core $1 \mathrm{O}$-glycans as well as $N$-glycans capped with $\alpha 2,6$-linked sialic acid, which inhibits galectin-1 binding (36).

Overall, glycosylation appears to play a critical role in the different stages of thymocyte development and in the generation of an efficient immune system. Nevertheless, further research is 
needed in order to understand how glycans control each stage of thymocytes development, differentiation and selection, which might reveal novels insights on the influence of the glycome in major diseases, such as autoimmunity and cancer.

\section{GLYCANS IN THE REGULATION OF T CELL ACTIVITY AND FUNCTIONS}

The proper function of T lymphocytes is highly dependent on their surface receptors, which in turn are highly mediated by glycosylation. Although $\mathrm{O}$-glycan structures have been shown to play important roles on immune-associated molecules (37), the prominent role of $\mathrm{N}$-linked glycans is emphasized in this section (Figure 2).

As previously mentioned, MHC I is expressed by almost all nucleated cells and interacts with TCRs on $\mathrm{CD} 8^{+} \mathrm{T}$ cells; in turn, MHC II is expressed by professional antigen presenting cells (APCs) (dendritic cells - DC, macrophages, B cells and TECs) and is recognized by $\mathrm{CD} 4^{+} \mathrm{T}$ cells $(7,38)$. More than 3 decades ago, it was demonstrated that blocking MHCla $\mathrm{N}$-glycosylation, through acceptor site mutation, results in significant increases in intracellular misfolded protein along with decreases in cell surface expression (39). MHC II is assembled by two glycoproteins, $\alpha$ and $\beta$ chains. The $\alpha$ chain contains $N$-linked high-mannose and complex glycans whereas the $\beta$ chain is only constituted by complex $N$-glycans (40). In contrast to the role of MHC I, MHC II glycosylation was shown to have a particular impact on the effective antigen binding, as well as in the presentation of microbial carbohydrate antigens, which consequently influences downstream $\mathrm{T}$ cell responses. This was demonstrated by the depletion of the Mgat2 gene, which compromises $\mathrm{N}$-glycan branching, decreasing carbohydrate antigen presentation by MHC class II and leading to loss of T cell stimulatory activity (41).

During TCR signal transduction, glycans play a key role in stabilizing individual molecules in the complexes at the immunological synapse and by protecting them from the action of proteases during T cell engagement (31). Additionally, glycans can also restrict nonspecific protein-protein interactions, like aggregation of TCRs on the membrane, helping to orient the interactions of the proteins in the central clusters (31). Demetriou et al. demonstrated that $\beta 1,6-$ GlcNAc branched $N$ glycans structures (catalyzed by GnT-V) regulate T cell activity, namely in $\mathrm{CD}^{+} \mathrm{T}$ cells by increasing the threshold of $\mathrm{T}$ cell activation, suppressing $\mathrm{T}$ cell growth and signaling $(30,42)$. Moreover, core-fucosylation, which refers to fucose attached to the innermost $\mathrm{N}$-acetylglucosamine of $\mathrm{N}$-linked glycans, catalyzed by $\alpha 1-6$ fucosyltransferase (FUT8), was also shown to affect $\mathrm{T}$ cell activity in immune mediated disorders $(42,43)$.

The $\mathrm{T}$ cell activity is also dependent on glycosylation of co-receptors, such as the complex formation between TCR and CD45. Galectin-3 is a key mediator of this complex, by establishing a molecular lattice through binding to polylactosamine structures in branched $\mathrm{N}$ glycans. Consequently, CD45 phosphatase activity induces downregulation of $\mathrm{T}$ cell signaling, preventing $\mathrm{T}$ cell activation
(44). Furthermore, CD45 is alternatively spliced into five different isoforms on human leukocytes (CD45ABC, CD45AB, CD45BC, CD45B, and CD45RO) (45-47), all decorated with up to $11 \mathrm{~N}$-glycans in the membrane proximal region. Importantly, all isoforms present different glycosylation profiles $(48,49)$, that change during $\mathrm{T}$ cell differentiation and activation $(50,51)$, as reviewed in (36). CD28 is another T cell surface glycoprotein acting as a secondary signaling molecule of $\mathrm{T}$ cell activation. Interestingly, nearly $50 \%$ of the molecular mass of CD28 is constituted by $\mathrm{N}$-glycans (52). Previous studies reported that $\mathrm{N}$-glycosylation of human $\mathrm{CD} 28$ can negatively regulate CD28-mediated T cell adhesion and co-stimulation, namely the interaction between CD28/CD80. Mutation of all potential $\mathrm{N}$-linked glycosylation sites of $\mathrm{CD} 28$ as well as treatment of Jurkat cells with inhibitors of $\mathrm{N}$-glycosylation pathway resulted in a defective CD28 glycosylation with enhancement of the binding to CD80 expressed on APCs (52). The branching $\mathrm{N}$-glycosylation of CD25 receptor also modulates its cell surface retention controlling $\mathrm{T}$ differentiation with impact in immune tolerance. Recently, it was demonstrated that a decreased UDP-GlcNAc and complex branching $\mathrm{N}$-glycosylation induces a decreased cell surface retention of CD25 and IL-2 signaling, promoting a $\mathrm{T}$ helper $\left(\mathrm{T}_{\mathrm{H}}\right) 17$ over induced regulatory $\mathrm{T}$ cell (iTreg) differentiation (53) (Figure 2).

Importantly, the co-inhibitory receptors are likewise modulated by $N$-glycosylation. One of the major negative regulators of $\mathrm{T}$ cell response is the cytotoxic T-lymphocyte protein 4 (CTLA-4), that comprises two $\mathrm{N}$-glycosylation sites described to modulate its cell surface retention on $\mathrm{T}$ cells and thereby its affinity for CD80/CD28 on APCs (54-56). The impact of $\mathrm{N}$-glycosylation in the modulation of the inhibitory functions of CTLA-4 and programmed cell death protein-1 (PD-1) is discussed in more detail in section "Glycans in tolerogenic/immunosuppressive responses". Nonetheless, other co-inhibitory receptors like Lymphocyte-activation gene 3 (Lag-3), mucin-domain-containing molecule-3 (Tim-3), and $\mathrm{T}$ cell immunoreceptor with Ig and ITIM domains (TIGIT) may also undergo glycans-mediated regulation, as they exhibit $\mathrm{N}$-glycan-binding sites, however the role of glycans on these molecules remains to be explored (57).

Taken together, $\mathrm{N}$-glycosylation plays an instrumental role in the regulation of $\mathrm{T}$ cell activation and functions by targeting not only TCR but also its co- receptors (Figure 2).

\section{GLYCANS AS MODULATORS OF HYPER-REACTIVE/AUTOIMMUNE RESPONSES}

Autoimmunity is characterized by the loss of self-tolerance and development of an autoreactive immune response toward the individual's own organism. Glycan motifs play a crucial role in the determination of self/non-self antigens. Specific glycan structures, expressed by microbial pathogens, are commonly responsible for the primary activation of the innate immune system; however, the mechanisms involved in the self/non-self discrimination, mediated by glycans are far from being fully 
elucidated. Abnormal levels of branched $N$-glycans have been associated with exacerbated immune responses in murine models (58). Particularly, the dysregulation of the $N$-glycosylation pathway has been associated with autoimmune-like phenotypes. The inability to synthetize $\beta 1,6$-GlcNAc antennae, in Mgat5 $5^{-/-}$ mice has been associated with an increased susceptibility to immune-mediated disorders such as an increased delayed-type hypersensitivity responses, as well as increased susceptibility to develop experimental autoimmune encephalomyelitis (EAE) (30, 59) and severe forms of colitis (60). The lack of $\beta 1,6$ branching $\mathrm{N}$-glycans favors TCR clustering, leading to a decrease of the TCR threshold and consequently increased $\mathrm{T}$ cell activation (30) associated with the hyperimmune response observed in these mice (Figure 2). This hyperimmune phenotype is also due to an abnormal formation of lattices between TCR-branched glycosylation and galectins $(61,62)$. Accordingly, $\beta 3$ GnT2deficient mice show $\mathrm{T}$ cell hypersensitivity due to the reduction of polylactosamine on the $\mathrm{N}$-glycans (ligands of galectins), similarly to what is observed in Mgat5 deficient mice $(30,61)$. Furthermore, absence of $\alpha$-mannosidase II (which catalyses the last hydrolysis of the $\alpha$-mannose), was shown to result in signs of glomerulonephritis, deposits of glomerular IgM immunocomplexes and complement component 3 as well as high levels of anti-nuclear antibodies $(63,64)$, which is consistent with a Lupus-like syndrome (Figure 2). Taken together, these evidences support the role of $\mathrm{N}$-glycosylation in the perspective of $\mathrm{T}$ cell biology.

The role of $\mathrm{N}$-glycans in antigen presentation and recognition is still elusive, and in fact abnormal glycoantigen presentation might also impact $\mathrm{T}$ cell activity. Abnormal accumulation of high-mannose, paucimannose, and agalactosyl bi-antennary glycans, have been detected in kidney tissue from MRL-lpr mouse (a well-stablished murine model of SLE) (65). Moreover, evidences have been showing that $M g a t 1^{\mathrm{f} / \mathrm{f}}$ Syn 1 -Cre mice, with Mgat1 deletion at the Synapsin I-expressing cells (abundant in neural tissues), presented neurological defects, with high levels of neuronal apoptosis and caspase 3 activation (66). These high levels of apoptosis are observed in several autoimmune diseases, which results in activation of immune system (67) (Figure 2). Although highly unexplored, rare autoimmune diseases are also associated with $\mathrm{N}$-glycosylation dysfunctions. As example, idiopathic inflammatory myopathies (IIM) are a group of rare diseases of autoimmune nature, whose etiopathogenesis is far from being totally understood (68). Muscle cells surface is enriched with glycoproteins and several lines of evidence provide support for a fundamental role of glycosylation in muscle homeostasis and function $(69,70)$. Glucosamine (UDP$N$-Acetyl)-2-Epimerase/ $N$-Acetylmannosamine Kinase (GNE) genetic mutations (a gene that encodes $\mathrm{N}$-acetylmannosamine (ManNAc) kinase enzyme, responsible for the biosynthesis of $\mathrm{N}$-acetylneuraminic acid) results in hypo-sialylation of muscle glycoproteins; the prophylactic supplementation with sialic acid precursor (ManNAc) was shown to prevent the muscle phenotype in mice with gene mutations that cause hereditary inclusion-body myositis (hIBM), a muscle phenotype that resembles one type of IIM (71). Altogether, these findings highlight the importance of further studies addressing the role of $\mathrm{N}$-glycosylation in the perspective of neoautoantigens, since autoantigens contain a significant amount of glycoantigens due to the increased number of $\mathrm{N}$-glycosylation sites comparing with other proteins (72).

The Glycan binding proteins (GBPs) are expressed in the APCs being characterized by a carbohydrate recognition domain which specifically recognizes glycan structures present at the cell surface receptors. This glycan-GBPs engagement results in either an anti- or pro-inflammatory response (73). C-type lectins, siglecs, and galectins are examples of GBPs, that are instructors of immune responses $(5,73)$. As example, SIGN1R (expressed by APCs and the analogous of the human dendritic cell-specific ICAM-grabbing non-integrin - DC-SIGN) signaling was shown to result in the expansion of IL-10-secreting Treg cells, preventing the development of autoimmune diseases such as EAE and type 1 diabetes (T1D) (74). Galectin-1 also plays an important immune-regulatory role in $\operatorname{EAE}(75)$ as mice deficient in galectin-1 (Lgals $1^{-/-}$) have increased $\mathrm{T}_{\mathrm{H}} 1$ and $\mathrm{T}_{\mathrm{H}} 17$ responses being more susceptible to EAE when compared with wild type mice (76). More recently, Galectin-1 was shown to modulate the cytolytic activity of $\mathrm{CD} 8^{+} \mathrm{T}$ cell. The interaction of Galectin-1 and Fas ligand seems to be responsible for the retention of this glycoprotein at the surface of cytotoxic $\mathrm{T}$ lymphocytes hampering the cytolytic ability of these cells (77). Overall, GBPs-glycoprotein interaction is essential to instruct a $\mathrm{T}$ cell—-mediated immune response.

Notably, one of the first evidences addressing the relationship between the dysregulation of $\mathrm{N}$-glycosylation and human autoimmunity was observed in multiple sclerosis (MS) patients. During active, relapse or in very early stages of remission, peripheral blood mononuclear cells from MS patients display a significant decrease of the enzymatic activity of Golgi $\beta 1,6 \mathrm{~N}$ acetylglucosaminyltransferase (core 2 GlcNAc-T), compared to healthy subjects (78). Moreover, MGAT5 polymorphisms were associated with MS severity (79) together with MGAT1, IL2R, and IL7R Single Nucleotide Polymorphisms (80-82). Additionally, in Inflammatory Bowel Disease (IBD), it was also demonstrated that lamina propria $\mathrm{T}$ lymphocytes from ulcerative colitis (UC) patients exhibited a deficiency in $\beta 1,6-$ GlcNAc branching $N$ glycans due to decreased levels of MGAT5 gene expression (83). Importantly, low levels of branched $\mathrm{N}$-glycans in lamina propria early at diagnosis were shown to predict UC patients that will fail the response to standard therapy, thus displaying a bad disease course (84). The supplementation of intestinal T cells from UC patients and mouse models with colitis with GlcNAc promoted the enhancement of $\beta 1,6$ branching $N$-glycans on T cells, suppressing TCR signaling and reducing the production of pro-inflammatory cytokines such as tumor necrosis factor alpha $(\mathrm{TNF} \alpha)$ and interferon gamma (IFN $\gamma$ ). Pre-clinical studies both in IBD and MS demonstrated the immunomodulatory properties of $\mathrm{N}$-glycans in the control of $\mathrm{T}$ cell-mediated immune response $(60,85)$, paving the way for the development of human clinical trials, that are currently on going $(53,60)$. Less explored but of utmost importance is the study of $\mathrm{N}$-glycosylation profile in rare autoimmune disorders, since its etiopathogenesis is still very elusive. Glycosylation changes in muscle-associated human disease have focused in muscular dystrophies (86) and congenital 
disorders of glycosylation (87). Recent studies have shown that muscle cell surface glycosylation is finely regulated and subjected to alterations under inflammatory conditions (88), pointing to a possible interaction between muscle glycocalyx and the extracellular milieu, which is particularly enriched in immune cells and antibodies in IIM patients (89).

Overall, glycans are critical determinants in autoreactive responses both by directly regulating $\mathrm{T}$ cell activity and also through the creation of abnormal glycoantigens that may unleash an autoreactive immune response.

\section{GLYCANS IN TOLEROGENIC/IMMUNOSUPPRESSIVE RESPONSES}

Recent studies have been highlighted that alterations on the glycosylation pattern of $\mathrm{T}$ cells' receptors, as well as the alterations of the glycosylation profile of tumor cells (tumor glyco-code), are implicated in the modulation of the immune response leading to immunosuppressive pathways, known to occur in the tumor microenvironment associated with tumor immunoescape (90).

\section{Role of Glycans in the Modulation of Inhibitory T Cell Receptors}

PD-1, as already introduced, is a cell surface inhibitory T cell receptor responsible for immune-inhibitory responses associated with the so-called "T cell exhaustion" (91). The expression of this cell surface receptor, as well as Tim-3, was described to be positively regulated by the core fucosylation pathway, catalyzed by FUT8 enzyme (92). The inhibition of core fucosylation in PD-1 was demonstrated to lead to an anti-tumor immune response mediated by $\mathrm{T}$ cells activation, being a new attractive target for enhancing anti-tumor immunity in future clinical settings (Figure 2). This was a pioneer study that supported the importance of $\mathrm{PD}-1$ post-translational modifications by glycosylation on $\mathrm{T}$ cell-mediated immunosuppression (92). Additionally, the glycosylation of programmed death ligand-1 (PD-L1), a PD-1 ligand, was described to have an important role in its cellular stabilization. The interaction of non-glycosylated PD-L1 with glycogen synthase kinase $3 \beta$ (GSK3 $\beta$ ), a key enzyme on glycogenesis, leads to the degradation of this molecule (93). In triple-negative breast cancer cells, it was further shown that the $\beta 1,3-N$-acetylglucosaminyl transferase (B3GNT3), involved in the biosynthesis of poly- $N$-acetyllactosamine chains, is important for the interaction between PD-1 and its ligand PD-L1 (94). The use of an antibody targeting the glycosylated form of PD-L1 resulted in its degradation and internalization, with the blockage of PD-L1/PD-1 interaction and consequently the inducement of anti-tumor activity in triple-negative breast cancer in vitro and in vivo models (94). In accordance, Tregs from healthy humans and mice were shown to display an increased variability on its $\mathrm{N}$-glycosylation pattern when compared with $\mathrm{CD} 4^{+} \mathrm{T}$ cells. The levels of the complex branched $\mathrm{N}$-glycans were shown to be correlated with the expression of proteins involved in Treg suppressive functions, including PD-1, PD-L1, and also other negative regulators of $\mathrm{T}$ cell response, namely CTLA- 4
(95). In fact, the CTLA-4 protein, comprises multiple $N$ - and $\mathrm{O}$-glycosylation sites known to modulate its retention at $\mathrm{T}$ cell surface and consequently affecting its function (56). The TCR activation is associated with an increased $\beta 1,6-$ GlcNAc branched $\mathrm{N}$-glycosylation of CTLA-4, which enhances CTLA-4 retention at the $\mathrm{T}$ cell surface and thereby suppresses $\mathrm{T}$ cell activation promoting immune tolerance (96) (Figure 2). Accordingly, the presence of Thr17Ala polymorphism in human CTLA-4 was shown to result in the reduction of the $\mathrm{N}$-glycosylation sites from one to two sites, which limited CTLA-4 retention at T cell surface (80). Supplementations with GlcNAc and Vitamin D promoted an enhancement of $\mathrm{N}$-glycans branching expression, increasing the cell surface retention of CTLA-4, culminating in immunosuppression (80).

\section{Glycans as Instructors of Immunosuppressive Responses}

Tumor cells aberrantly express different types of glycans structures when compared with normal counterparts, such as an increased sialylation, an expression of truncated glycans and an overexpression of branched $\mathrm{N}$-glycans (97). This alteration in the cellular glycosylation profile governs several steps of tumor development and progression, such as tumor cell dissociation, proliferation, invasion, metastasis, angiogenesis, with recent evidences pointing toward its effects in tumor immunoediting and immunosurveillance (98). GBPs expressed on immune cells are able to recognize altered glycan structures expressed at tumor cell surfaces instructing either immunostimulatory or immunoinhibitory responses.

The expression of sialylated glycans, such as Tn antigen and Lewis antigens, aberrantly expressed in tumor cells, were described to be recognized by DC-SIGN, expressed by macrophages and immature DCs, which lead to immunosuppression (99). The fucose residues present in Lewis structures (Lewis $\mathrm{x}$ and Lewis $\mathrm{y}$ ), attached to carcinoembryonic antigen (CEA) (100), were described to trigger the upregulation of the anti-inflammatory cytokines IL-10 and IL-27 by APCs and the induction of $\mathrm{T}_{\mathrm{H}}$ 2, follicular $\left(\mathrm{T}_{\mathrm{H}} \mathrm{f}\right)$, and Treg immune responses $(101,102)$. Besides, antigen-containing liposomes modified with DC-SIGN-binding Lewis $\mathrm{b}$ and $\mathrm{x}$ resulted in glycans recognition and internalization through DCs with consequent activation of $\mathrm{CD}^{+}$and $\mathrm{CD}^{+} \mathrm{T}$ cells (103). Furthermore, macrophage galactose binding lectin (MGL) was found to be able to recognize Tn antigen and $\mathrm{N}$ acetylgalactosamine (GalNAc) residues, resulting in an increased recognition by Toll-like receptor 2 , ultimately resulting in the secretion of cytokines (IL-10 and TNF- $\alpha$ ). (104). Its interaction with terminal GalNAc residues on CD45 glycoprotein negatively regulates TCR signaling, with consequent decrease of $\mathrm{T}$ cell proliferation and increased $\mathrm{T}$ cell death (105). Moreover, by blocking the tumor-infiltrated macrophages (responsible for the high levels of IL-10), it was observed an effective $\mathrm{CD} 8^{+}$ $\mathrm{T}$ cells response, highlighting the importance of combining anti-tumor immune therapy with conventional chemotherapy (106). Furthermore, it was recently demonstrated in chronic infection that IL-10 induces the upregulation of the Mgat5 
gene increasing branched $\mathrm{N}$-glycans on $\mathrm{CD}^{+} \mathrm{T}$ cells, which in turn decreases $\mathrm{T}$ cell activity and allows viral persistence (107). Despite the different context in which this hypothesis was studied, Mgat5-mediated branching glycosylation can constitute a potential mechanism by which IL-10 is suppressing $\mathrm{CD}^{+} \mathrm{T}$ cells in cancer.

In addition, sialylated glycans also play a role in immunosuppression, mediated by siglecs, a family of lectin receptors that predominantly exhibit immune-inhibitory functions. In in vitro and in vivo studies, the binding to sialylated antigens by siglec-E expressed on DCs promoted an increase of antigen-specific Treg response and a reduced numbers of antigen-specific Teff cell response, associated with tumor growth $(108,109)$. Indeed, the sialylated tumor antigens, such as Sialyl-Tn (sTn) and Sialyl-T (sT) expressed in mucins, namely MUC1, were associated with tumor immune tolerance. The recognition of MUC1-ST by siglec- 9 on tumorinfiltrating macrophages was shown to initiate inhibitory immune pathways mediated by MEK-ERK signaling (110). Moreover, siglec-binding to sTn-expressing mucins, led to the maturation of DCs and DC-mediated induction of FOXP3 ${ }^{+}$ Treg cells and reduced INF $\gamma$-producing T cells $(111,112)$. A recent study also demonstrates that siglec- 9 expressed by $\mathrm{CD} 8^{+}$ tumor infiltrating lymphocytes (TILs) in non-small cell lung cancer (NSCLC) patients was associated with reduced survival. Accordingly, siglec- 9 polymorphisms were associated with the risk of developing lung and colorectal cancer. Additionally, the characterization of siglec- $9^{+} \mathrm{CD} 8^{+}$TILs revealed that these cells concomitantly express several inhibitory receptors, including PD-1, TIM-3, Lag3, and others. In addition, the same study further reveals that lack of sialic acid-containing glycans in tumor cells led to a delay of tumor growth and an increased infiltration of $\mathrm{CD}^{+}$and $\mathrm{CD} 8^{+}$T cells (113).

Another important GBP that have been pointed out as a crucial checkpoint in $\mathrm{T}$ cell viability and activity are galectins. Galectin-1, 3, and 9 were predominantly described in $\mathrm{T}$ cell immunosuppression. Galectin-1, was demonstrated to be expressed by tolerogenic DCs (75) and $\mathrm{CD} 4{ }^{+} \mathrm{CD} 25^{+}$ $\mathrm{T}$ cells (114), triggering $\mathrm{T}$ cell apoptosis through binding to $N$-glycans and O-glycans on CD45, CD43, and CD7 or by sensitizing resting $\mathrm{T}$ cells to FAS-induced death $(115,116)$. The $\mathrm{T}_{\mathrm{H}} 1$ and $\mathrm{T}_{\mathrm{H}} 17$ activated cells are susceptible to galectin1 -induced cell death once these cells express the repertoire of glycans required for galectin-1 binding, while $\mathrm{T}_{\mathrm{H}} 2$ cells are protected via $\alpha 2,6$-sialylation on cell surface glycoproteins, which was described to preclude galectin-1 recognition and binding (76). In addition, several tumors have the capacity to secrete galectin-1 in order to promote immunosuppression, through a mechanism that involves a bias toward a $\mathrm{T}_{\mathrm{H}} 2$ cytokine profile and activation of tolerogenic circuits mediated by IL-27-producing DCs and IL-10-producing type 1 Treg cells (117). On other hand, galectin-3 has an ambiguous role in $\mathrm{T}$ cell viability: when it is localized at intracellular level, this protein presents a protective role through a cell death inhibition pathway that involves B-cell lymphoma 2 (Bcl-2) (118), whereas extracellular galectin-3 induces cell death in activated $\mathrm{T}$ cells, by binding to glycosylated receptors of $\mathrm{T}$ cells through a distinct way than galectin-1 (115). Moreover, galectin-3 has the capacity to bind to $N$-glycans on CTLA-4 prolonging the inhibitory signals (119), as well as to Lag-3 on the surface of $\mathrm{CD}^{+} \mathrm{T}$ cells, suppressing its function (120). Finally, galectin-9 abrogates $\mathrm{T}_{\mathrm{H}} 1, \mathrm{~T}_{\mathrm{H}} 17$, and $\mathrm{CD} 8^{+} \mathrm{T}$ cells through glycosylationdependent binding to Tim-3 (121-123), whereas may regulate pro-inflammatory cytokine production by binding with other receptors (124).

Altogether, these findings support the relevance of glycans on $\mathrm{T}$ cells-mediated immunosuppressive/tolerogenic pathways which have relevant implications in tumor progression. Targeting the abnormal glycosylation pattern of cancer cells constitutes a promising strategy to instruct an effective anti-tumor immune response, an issue that needs to be further explored.

\section{GLYCANS AS METABOLIC REGULATORS OF T CELL FUNCTION}

The impact of glycosylation on T cell development and functions is enormous, as revealed by the critical roles of glycans in the development and progression of major diseases such as auto-immunity and cancer, as described herein. In order to accompany the bioenergetic and biosynthetic demands required for $\mathrm{T}$ cell proliferation and activation, a shift in the $\mathrm{T}$ cell metabolism is required. While naïve $\mathrm{T}$ cells are in a metabolic quiescent state, mainly using oxidative phosphorylation to maximize ATP production, T cells under clonal expansion or under differentiation, reprogram their metabolic status to aerobic glycolysis and glutaminolysis in order to increase the availability of glycolytic precursors for the biosynthesis of nucleotides, amino acids and lipids (125-127). During $\mathrm{T}$ cell activation, the hexosamine biosynthetic pathway ( $\mathrm{HBP}-\mathrm{a}$ branch of the glucose metabolism) is upregulated in order to generate the nucleotide sugar-donor substrate UDP-GlcNAc, required for $\mathrm{N}$-glycosylation, O-GlcNAcylation, and glycosaminoglycans production that are needed for a proper T cell function (128).

Mediators from the glycolytic pathway such as glucose (Glc), glutamine $(\mathrm{Gln})$, acetyl $\mathrm{CoA}$ are known to interfere with the availability of the UDP-GlcNAc in the cell (129-131). Together Glc and Gln were shown to increase UDP-GlcNAc in nutrientstarved T cells. In the same setup, the supplementation of both Glc and glucosamine (GlcN-a metabolite of the HBP) further increased the UDP-GlcNAc cellular content, demonstrating the sensitivity of the HBP to nutrients that enter directly (GlcN) or through a precursor pathway (Glc in glycolysis) (130). Despite the general use of the UDP-GlcNAc as a substrate donor of HBP, there are some glycosyltransferases that are more susceptible to nutrient changing than others, such as the case of OGT (132). In fact, the supply with Glc and Gln are crucial for protein O-GlcNAcylation, that is important during $\mathrm{T}$ cell development, being associated with T cell malignant transformation (23). Among the $\mathrm{N}$ acetylglucosaminyltransferases (GnTs) that participate in the HBP, the less sensitive to nutrient changing (and thus substrate availability) are GnT1, GnT2, and GnT3, due to lower Michaelis Constant $\left(K_{m}\right)$ levels, meaning that these enzymes require low 
levels of the substrate to synthetize the specific glycans. In contrast, GnT4 and GnT5 present higher $K_{m}$ and therefore their activity is highly dependent on the availability of the UDPGlcNAc substrate $(119,133)$. Therefore, these two enzymes are sensitive to alterations in glucose and HBP metabolism (as the GlcN or $N$-acetyl glucosamine-GlcNAc) (62), which ultimately will interfere in the $\mathrm{N}$-glycan branching biosynthesis on $\mathrm{T}$ cells with impact in their activity, as detailed in section "Glycans in the regulation of T cell activity and functions" (60). In fact, supplementation with Glc, Gln, and GlcNAc increases branching $\mathrm{N}$-glycans on Jurkat cells and resting T cells from mice $(85,119,130)$. Moreover, CD4 ${ }^{+} \mathrm{T}$ cells from MGAT5 $5^{+/+}$or MGAT5 $^{+--}$mice supplemented with oral GlcNAc also results in up to $40 \%$ increase of branching $N$-glycans, detected by L-PHA (130). This enhancement of branching $N$-glycosylation upon GlcNAc supplementation was shown to functionally impact on $\mathrm{T}$ cells activity by reducing $\mathrm{T}$ cell activation, decreasing $\mathrm{T}_{\mathrm{H}} 1$ differentiation, and increasing retention of the growth inhibitory receptor CTLA- 4 at $\mathrm{T}$ cell surface $(85,130)$.

Importantly, evidences suggest that the glycolysis and glutaminolysis compete with HBP pathway for the same metabolites. Recently, Araujo et al showed that, during $\mathrm{T}_{\mathrm{H}} 17$ differentiation the existence of common mediators shared between HBP, glycolysis (fructose-6-phosphate) and glutaminolysis (Gln) results in a starvation of the HBP mediators, translated in a reduction of $\mathrm{N}$-glycan branching due to the limitation on the UDP-GlcNAc availability (53). Fueling HBP with GlcNAc switched the cell fate from $\mathrm{T}_{\mathrm{H}} 17$ to iTreg differentiation, through stimulation of IL2-R $\alpha$ signaling (53). This interplay between metabolic pathways was further demonstrated by the increase on Glc, Gln, fatty-acids uptake, and lipid storage upon stimulation of the HBP with GlcNAc supplementation, suggesting a reprogramming of the cellular metabolism upon GlcNAc flux $(53,134)$.

The impact of glycans as metabolic regulators of $\mathrm{T}$ cells is also testified by its effects in ex vivo and in vivo models of autoimmune diseases. The metabolic supplementation with GlcNAc in ex vivo human colonic T cells from IBD patients resulted in an enhancement of the branching $N$-glycosylation pathway that was accompanied by a significant reduction of $\mathrm{T}$ cell proliferation, supression of $\mathrm{T}_{\mathrm{H}} 1 / \mathrm{T}_{\mathrm{H}} 17$ immune response (through decreased production of IFN- $\gamma$ and IL-17A proinflammatory cytokines) and decreased TCR signaling (60). Accordingly, the GlcNAc supplementation of mice models with auto-immune diseases such as EAE, TID, and IBD results in inhibition of $\mathrm{T}_{\mathrm{H}} 1, \mathrm{~T}_{\mathrm{H}} 17$ immune response concomitantly with a significant improvement of the clinical symptoms $(60,85)$. Treatment with GlcNAc after disease onset also demonstrate inhibitory effects on the development of the EAE, by reducing the secretion of INF- $\gamma$, TNF- $\alpha$, IL-17, and IL-22 (85). Interestingly, a dual role of GlcN (the precursor of GlcNAc) on the progression of autoimmune disorders was shown, by demonstrating its impact in preventing $\mathrm{T}_{\mathrm{H}}$ 1-mediated Type I diabetes (through the reduction of IFN $-\gamma$ producing $\mathrm{CD} 4^{+} \mathrm{T}$ cells), but also the $\mathrm{GlcN}$ effects in exacerbating $\mathrm{T}_{\mathrm{H}} 1 / \mathrm{T}_{\mathrm{H}} 17$-mediated EAE symptoms (trough stimulation of $\mathrm{T}_{\mathrm{H}} 17$ response) (135). In contrast, another study showed that GlcN suppresses acute EAE through the blockage of $\mathrm{T}_{\mathrm{H}} 1$ and induction of $\mathrm{T}_{\mathrm{H}} 2$ response (136). GlcN supplementation was further shown to mediate $\mathrm{T}$ cell activation by decreasing the $\mathrm{N}$-glycosylation of CD25 (IL-2R $\alpha$ ) from $\mathrm{CD} 4^{+}$ $\mathrm{T}$ cell (135). This down-regulation of $\mathrm{N}$-glycosylation might be explained by the competition between GlcN and Glc for the same glucose transporter which might impact in the reduction of the GlcNAc concentration.

Altogether, alterations on the glucose metabolism and partially changes in the metabolic flux of HBP have a direct impact on $\mathrm{T}$ cells $\mathrm{N}$-glycosylation profile with major consequences in their function and activity. Ultimately, the modulation of the HBP constitutes an important metabolic target able to control both autoreactive and immunosuppressive responses known to occur, respectively, in autoimmunity and cancer.

\section{CONCLUDING REMARKS}

The contribution of the glycome as a major regulator of the immune system is clear. Glycans actively participate in the cellular and molecular mechanisms underlying the genesis of the loss of immunological tolerance associated with (auto)immunity, from one hand, participating also in the creation of tolerogenic pathways associated with cancer progression, from the other. The importance of glycans in immune response spans from its role in the modulation the $\mathrm{T}$ cell development; their importance as a source of glycoantigens presentation; as well as their role as fine tuners of $\mathrm{T}$ cell response. In this context, glycans can exert a dual role, acting either as immune inhibitory checkpoints or as immune stimulatory signals. Understanding in depth the influence of glycans in the immune regulatory circuits that mediate the pathophysiology of autoimmunity and cancer will generate a platform with extraordinary potential to illuminate the identification of novel biomarkers and targets for the development of efficient immunomodulatory strategies with applications in the clinical setting.

\section{AUTHOR CONTRIBUTIONS}

All the authors wrote the manuscript. $\mathrm{AD}$ and $\mathrm{NP}$ created the figures. SP performed the critical review of the manuscript.

\section{FUNDING}

The Institute of Molecular Pathology and Immunology of the University of Porto integrates the i3S research unit, which is partially supported by the Portuguese Foundation for Science and Technology (FCT). This article is a result of the project NORTE-01-0145-FEDER-000029, supported by the Norte Portugal Regional Programme (NORTE 2020) under the PORTUGAL 2020 Partnership Agreement through the European Regional Development Fund. This work was also funded by Fundo Europeu de Desenvolvimento Regional (FEDER) funds through the COMPETE 2020-Operacional Programme for Competitiveness and Internationalization (POCI), Portugal 
2020, and by Portuguese funds through the FCT in the framework of the project (POCI-01/ 0145-FEDER-016601 and PTDC/DTP-PIC/0560/2014, as well as POCI-01-0145FEDER-028772). SSP acknowledges the European Crohn's and Colitis Organization (ECCO) for ECCO Grant 2017, the Broad Medical Research Program at the Crohn's and Colitis Foundation of America, and the Portuguese Group of Study in IBD (GEDII) for funding. MSP [SFRH/BD/110148/2015], IA

\section{REFERENCES}

1. Di Lella S, Sundblad V, Cerliani JP, Guardia CM, Estrin DA, Vasta GR, et al. When galectins recognize glycans: from biochemistry to physiology and back again. Biochemistry (2011) 50:7842-57. doi: 10.1021/bi201121m

2. Vasta GR, Feng C, González-Montalbán N, Mancini J, Yang L, Abernathy K, et al. Functions of galectins as 'self/non-self'-recognition and effector factors. Pathog Dis. (2017) 75:ftx046. doi: 10.1093/femspd/ftx046

3. Brown GD, Willment JA, Whitehead L. C-type lectins in immunity and homeostasis. Nat Rev Immunol. (2018) 18:374-89. doi: 10.1038/s41577-018-0004-8

4. Macauley MS, Crocker PR, Paulson JC. Siglec-mediated regulation of immune cell function in disease. Nat Rev Immunol. (2014) 14:653-66. doi: $10.1038 /$ nri3737

5. Bochner BS, Zimmermann N. Role of siglecs and related glycan-binding proteins in immune responses and immunoregulation. J Allergy Clin Immunol. (2015) 135:598-608. doi: 10.1016/j.jaci.2014.11.031

6. Varki A, Cummings RD, Esko JD, Stanley P, Hart GW, Aebi M, et al., editors. Essentials of Glycobiology. 3rd ed. New York, NY: Cold Spring Harbor (2015).

7. Johnson JL, Jones MB, Ryan SO, Cobb BA. The regulatory power of glycans and their binding partners in immunity. Trends Immunol. (2013) 34:290-8. doi: 10.1016/j.it.2013.01.006

8. Koch U, Radtke F. Mechanisms of $\mathrm{T}$ cell development and transformation. Annu Rev Cell Dev Biol. (2011) 27:539-62. doi: 10.1146/annurev-cellbio-092910-154008

9. Kumar BV, Connors TJ, Farber DL. Human T cell development, localization, and function throughout life. Immunity (2018) 48:202-13. doi: 10.1016/j.immuni.2018.01.007

10. Krueger A, Zietara N, Łyszkiewicz M. T cell development by the numbers. Trends Immunol. (2017) 38:128-39. doi: 10.1016/j.it.2016.10.007

11. Rossi FMV, Corbel SY, Merzaban JS, Carlow DA, Gossens K, Duenas J, et al. Recruitment of adult thymic progenitors is regulated by P-selectin and its ligand PSGL-1. Nat Immunol. (2005) 6:626-34. doi: 10.1038/ni1203

12. Sultana DA, Zhang SL, Todd SP, Bhandoola A. Expression of functional P-selectin glycoprotein ligand 1 on hematopoietic progenitors is developmentally regulated. J Immunol. (2012) 188:4385-93. doi: 10.4049/jimmunol.1101116

13. Shah DK, Zú-iga-Pflücker JC. An overview of the intrathymic intricacies of $\mathrm{T}$ cell development. J Immunol. (2014) 192:4017-23. doi: 10.4049/jimmunol.1302259

14. Rampal R, Li ASY, Moloney DJ, Georgiou SA, Luther KB, Nita-Lazar $A$, et al. Lunatic fringe, manic fringe, and radical fringe recognize similar specificity determinants in O-fucosylated epidermal growth factorlike repeats. J Biol Chem. (2005) 280:42454-63. doi: 10.1074/jbc.M5095 52200

15. Matsuura A, Ito M, Sakaidani Y, Kondo T, Murakami K, Furukawa K, et al. Olinked $\mathrm{N}$-acetylglucosamine is present on the extracellular domain of notch receptors. J Biol Chem. (2008) 283:35486-95. doi: 10.1074/jbc.M806202200

16. Song Y, Kumar V, Wei HX, Qiu J, Stanley P. Lunatic, manic, and radical fringe each promote T and B cell development. J Immunol. (2016) 196:232-43. doi: 10.4049/jimmunol.1402421

17. Koch U, Lacombe TA, Holland D, Bowman JL, Cohen BL, Egan $\mathrm{SE}$, et al. Subversion of the T/B lineage decision in the thymus by lunatic fringe-mediated inhibition of notch-1. Immunity (2001) 15:225-36. doi: 10.1016/S1074-7613(01)00189-3
[SFRH/BD/128874/2017], MV [PD/BD/135452/2017], received funding from the FCT.

\section{ACKNOWLEDGMENTS}

AC acknowledges Group of Studies for Autoimmune diseases from Portuguese Society of Internal Medicine (NEDAI) for funding.

18. Visan I, Yuan JS, Tan JB, Cretegny K, Guidos CJ. Regulation of intrathymic T-cell development by lunatic fringe? Notch1 interactions. Immunol Rev. (2006) 209:76-94. doi: 10.1111/j.0105-2896.2006.00360.x

19. Boudil A, Matei IR, Shih HY, Bogdanoski G, Yuan JS, Chang SG, et al. IL-7 coordinates proliferation, differentiation and Tcra recombination during thymocyte $\beta$-selection. Nat Immunol. (2015) 16:397-405. doi: 10.1038/ni.3122

20. Visan I, Yuan JS, Liu Y, Stanley P, Guidos CJ. Lunatic Fringe enhances competition for Delta-like Notch ligands but does not overcome defective pre-TCR signaling during thymocyte $\beta$-selection in vivo. J Immunol. (2010) 185:4609-17. doi: 10.4049/jimmunol.1002008

21. Hart GW, Housley MP, Slawson C. Cycling of O-linked $\beta-\mathrm{N}$ acetylglucosamine on nucleocytoplasmic proteins. Nature (2007) 446:1017-22. doi: 10.1038/nature05815

22. Hart GW. Minireview series on the thirtieth anniversary of research on OGlcNAcylation of nuclear and cytoplasmic proteins: nutrient regulation of cellular metabolism and physiology by O-GlcNAcylation. J Biol Chem. (2014) 289:34422-3. doi: 10.1074/jbc.R114.609776

23. Swamy M, Pathak S, Grzes KM, Damerow S, Sinclair L V, van Aalten DMF, et al. Glucose and glutamine fuel protein O-GlcNAcylation to control T cell self-renewal and malignancy. Nat Immunol. (2016) 17:712-20. doi: $10.1038 /$ ni.3439

24. Chou TY, Hart GW, Dang CV. c-Myc is glycosylated at threonine 58, a known phosphorylation site and a mutational hot spot in lymphomas. J Biol Chem. (1995) 270:18961-5. doi: 10.1074/jbc.270.32.18961

25. Marino JH, Tan C, Davis B, Han ES, Hickey M, Naukam R, et al. Disruption of thymopoiesis in ST6Gal I-deficient mice. Glycobiology (2008) 18:719-26. doi: 10.1093/glycob/cwn051

26. Bi S, Baum LG. Sialic acids in T cell development and function. Biochim Biophys Acta (2009) 1790:1599-610. doi: 10.1016/j.bbagen.2009.07.027

27. Moody AM, Chui D, Reche PA, Priatel JJ, Marth JD, Reinherz EL. Developmentally regulated glycosylation of the CD $8 \alpha \beta$ coreceptor stalk modulates ligand binding. Cell (2001) 107:501-12. doi: 10.1016/S0092-8674(01)00577-3

28. Shih HY, Hao B, Krangel MS. Orchestrating T-cell receptor $\alpha$ gene assembly through changes in chromatin structure and organization. Immunol Res. (2011) 49:192-201. doi: 10.1007/s12026-010-8181-y

29. Takaba H, Takayanagi H. The mechanisms of T cell selection in the thymus. Trends Immunol. (2017) 38:805-16. doi: 10.1016/j.it.2017.07.010

30. Demetriou M, Granovsky M, Quaggin S, Dennis JW. Negative regulation of T-cell activation and autoimmunity by Mgat5 N-glycosylation. Nature (2001) 409:733-9. doi: 10.1038/35055582

31. Rudd PM, Wormald MR, Stanfield RL, Huang M, Mattsson N, Speir JA, et al. Roles for glycosylation of cell surface receptors involved in cellular immune recognition. J Mol Biol. (1999) 293:351-66. doi: 10.1006/jmbi.1999.3104

32. Kuball J, Hauptrock B, Malina V, Antunes E, Voss RH, Wolfl M, et al. Increasing functional avidity of TCR-redirected T cells by removing defined $\mathrm{N}$-glycosylation sites in the TCR constant domain. J Exp Med. (2009) 206:463-75. doi: 10.1084/jem.20082487

33. Daniels MA, Devine L, Miller JD, Moser JM, Lukacher AE, Altman $\mathrm{JD}$, et al. CD8 binding to MHC class I molecules is influenced by $\mathrm{T}$ cell maturation and glycosylation. Immunity (2001) 15:1051-61. doi: 10.1016/S1074-7613(01)00252-7

34. Zhou RW, Mkhikian H, Grigorian A, Hong A, Chen D, Arakelyan A, et al. $\mathrm{N}$-glycosylation bidirectionally extends the boundaries of thymocyte positive 
selection by decoupling Lck from Ca2+ signaling. Nat Immunol. (2014) 15:1038-45. doi: 10.1038/ni.3007

35. Artyomov MN, Lis M, Devadas S, Davis MM, Chakraborty AK. CD4 and CD8 binding to MHC molecules primarily acts to enhance Lck delivery. Proc Natl Acad Sci USA. (2010) 107:16916-21. doi: 10.1073/pnas.1010568107

36. Clark MC, Baum LG. T cells modulate glycans on CD43 and CD45 during development and activation, signal regulation, and survival. Ann N Y Acad Sci. (2012) 1253:58-67. doi: 10.1111/j.1749-6632.2011.06304.x

37. Marth JD, Grewal PK. Mammalian glycosylation in immunity. Nat Rev Immunol. (2008) 8:874-87. doi: 10.1038/nri2417

38. Rossy J, Williamson DJ, Benzing C, Gaus K. The integration of signaling and the spatial organization of the T cell synapse. Front Immunol. (2012) 3:352. doi: 10.3389/fimmu.2012.00352

39. Barbosa JA, Santos-Aguado J, Mentzer SJ, Strominger JL, Burakoff SJ, Biro PA. Site-directed mutagenesis of class I HLA genes. Role of glycosylation in surface expression and functional recognition. J Exp Med. (1987) 166:132950. doi: $10.1084 /$ jem.166.5.1329

40. Unanue ER, Turk V, Neefjes J. Variations in MHC Class II antigen processing and presentation in health and disease. Annu Rev Immunol. (2016) 34:26597. doi: 10.1146/annurev-immunol-041015-055420

41. Ryan SO, Bonomo JA, Zhao F, Cobb BA. MHCII glycosylation modulates Bacteroides fragilis carbohydrate antigen presentation. J Exp Med. (2011) 208:1041-53. doi: 10.1084/jem.20100508

42. Dias AM, Pereira MS, Padrão NA, Alves I, Marcos-Pinto R, Lago P, et al. Glycans as critical regulators of gut immunity in homeostasis and disease. Cell Immunol. (2018). doi: 10.1016/j.cellimm.2018.07.007. [Epub ahead of print].

43. Fujii $H$, Shinzaki S, Iijima $H$, Wakamatsu K, Iwamoto C, Sobajima $T$, et al. Core Fucosylation on $\mathrm{T}$ cells, required for activation of $\mathrm{T}$-cell receptor signaling and induction of colitis in mice, is increased in patients with inflammatory bowel disease. Gastroenterology (2016) 150:1620-32. doi: 10.1053/j.gastro.2016.03.002

44. Wolfert MA, Boons GJ. Adaptive immune activation: glycosylation does matter. Nat Chem Biol. (2013) 9:776-84. doi: 10.1038/nchembio.1403

45. Hermiston ML, Xu Z, Weiss A. CD45: a critical regulator of signaling thresholds in immune cells. Annu Rev Immunol. (2003) 21:107-37. doi: 10.1146/annurev.immunol.21.120601.140946

46. Ohta T, Kitamura K, Maizel AL, Takeda A. Alterations in CD45 glycosylation pattern accompanying different cell proliferation states. Biochem Biophys Res Commun. (1994) 200:1283-9. doi: 10.1006/bbrc. 1994.1590

47. Rogers PR, Pilapil S, Hayakawa K, Romain PL, Parker DC. CD45 alternative exon expression in murine and human $\mathrm{CD} 4+\mathrm{T}$ cell subsets. J Immunol. (1992) 148:4054-65.

48. Furukawa K, Funakoshi Y, Autero M, Horejsi V, Kobata A, Gahmberg CG. Structural study of the O-linked sugar chains of human leukocyte tyrosine phosphatase CD45. Eur J Biochem. (1998) 251:288-94. doi: 10.1046/j.1432-1327.1998.2510288.x

49. Zapata JM, Pulido R, Acevedo A, Sanchez-Madrid F, de Landazuri MO. Human CD45RC specificity. A novel marker for $\mathrm{T}$ cells at different maturation and activation stages. J Immunol. (1994) 152:3852-61.

50. Daniels MA, Hogquist KA, Jameson SC. Sweet "n" sour: the impact of differential glycosylation on T cell responses. Nat Immunol. (2002) 3:903-10. doi: 10.1038/ni1002-903

51. Garcia GG, Berger SB, Sadighi Akha AA, Miller RA. Age-associated changes in glycosylation of CD43 and CD45 on mouse CD4 T cells. Eur J Immunol. (2005) 35:622-31. doi: 10.1002/eji.200425538

52. Aruffo A, Seed B. Molecular cloning of a CD28 cDNA by a high-efficiency COS cell expression system. Proc Natl Acad Sci USA. (1987) 84:8573-7. doi: 10.1073 /pnas.84.23.8573

53. Araujo L, Khim P, Mkhikian H, Mortales CL, Demetriou M. Glycolysis and glutaminolysis cooperatively control $\mathrm{T}$ cell function by limiting metabolite supply to N-glycosylation. Elife (2017) 6:1-16. doi: 10.7554/eLife.21330

54. Chen L, Ashe S, Brady WA, Hellstrom I, Hellstrom KE, Ledbetter JA, et al. Costimulation of antitumor immunity by the B7 counterreceptor for the T lymphocyte molecules CD28 and CTLA-4. Cell (1992) 71:1093-102. doi: 10.1016/S0092-8674(05)80059-5
55. Alegre ML, Frauwirth KA, Thompson CB. T-cell regulation by CD28 and CTLA-4. Nat Rev Immunol. (2001) 1:220-8. doi: 10.1038/351 05024

56. Zhu L, Guo Q, Guo H, Liu T, Zheng Y, Gu P, et al. Versatile characterization of glycosylation modification in CTLA4-Ig fusion proteins by liquid chromatography-mass spectrometry. MAbs (2014) 6:1474-85. doi: $10.4161 / \mathrm{mabs} .36313$

57. Monney L, Sabatos CA, Gaglia JL, Ryu A, Waldner H, Chernova $\mathrm{T}$, et al. Th1-specific cell surface protein Tim-3 regulates macrophage activation and severity of an autoimmune disease. Nature (2002) 415:536-41. doi: $10.1038 / 415536 \mathrm{a}$

58. Maverakis E, Kim K, Shimoda M, Gershwin ME, Patel F, Wilken R, et al. Glycans in the immune system and the altered glycan theory of autoimmunity: a critical review. J Autoimmun. (2015) 57:1-13. doi: 10.1016/j.jaut.2014.12.002

59. Lee SU, Grigorian A, Pawling J, Chen IJ, Gao G, Mozaffar T, et al. $\mathrm{N}$-glycan processing deficiency promotes spontaneous inflammatory demyelination and neurodegeneration. J Biol Chem. (2007) 282:33725-34. doi: 10.1074/jbc.M704839200

60. Dias AM, Correia A, Pereira MS, Almeida CR, Alves I, Pinto V, et al. Metabolic control of $\mathrm{T}$ cell immune response through glycans in inflammatory bowel disease. Proc Natl Acad Sci USA. (2018) 115:E4651-60. doi: 10.1073/pnas. 1720409115

61. Togayachi A, Kozono Y, Ishida H, Abe S, Suzuki N, Tsunoda Y, et al. Polylactosamine on glycoproteins influences basal levels of lymphocyte and macrophage activation. Proc Natl Acad Sci USA. (2007) 104:15829-34. doi: 10.1073/pnas.0707426104

62. Mkhikian H, Mortales CL, Zhou RW, Khachikyan K, Wu G, Haslam $\mathrm{SM}$, et al. Golgi self-correction generates bioequivalent glycans to preserve cellular homeostasis. Elife (2016) 5:e14814. doi: 10.7554/eLife.14814

63. Chui D, Sellakumar G, Green R, Sutton-Smith M, McQuistan T, Marek K, et al. Genetic remodeling of protein glycosylation in vivo induces autoimmune disease. Proc Natl Acad Sci USA. (2001):1142-7. doi: 10.1073/pnas.98.3.1142

64. Green RS, Stone EL, Tenno M, Lehtonen E, Farquhar MG, Marth JD. Mammalian $\mathrm{N}$-glycan branching protects against innate immune self-recognition and inflammation in autoimmune disease pathogenesis. Immunity (2007) 27:308-20. doi: 10.1016/j.immuni.2007.06.008

65. Hashii N, Kawasaki N, Itoh S, Nakajima Y, Kawanishi T, Yamaguchi $\mathrm{T}$. Alteration of $\mathrm{N}$-glycosylation in the kidney in a mouse model of systemic lupus erythematosus: relative quantification of $\mathrm{N}$-glycans using an isotope-tagging method. Immunology (2009) 126:336-45. doi: 10.1111/j.1365-2567.2008.02898.x

66. Ye Z, Marth JD. N-glycan branching requirement in neuronal and postnatal viability. Glycobiology (2004) 14:547-58. doi: 10.1093/glycob/cwh069

67. Darrah E, Andrade F. NETs: the missing link between cell death and systemic autoimmune diseases? Front Immunol. (2013) 3:428. doi: 10.3389/fimmu.2012.00428

68. Miller FW, Lamb JA, Schmidt J, Nagaraju K. Risk factors and disease mechanisms in myositis. Nat Rev Rheumatol. (2018) 14:255-68. doi: 10.1038/nrrheum.2018.48

69. McMorran BJ, McCarthy FE, Gibbs EM, Pang M, Marshall JL, Nairn A V, et al. Differentiation-related glycan epitopes identify discrete domains of the muscle glycocalyx. Glycobiology (2016) 26:1120-32. doi: $10.1093 /$ glycob/cww061

70. Townsend D. Finding the sweet spot: assembly and glycosylation of the dystrophin-associated glycoprotein complex. Anat Rec. (2014) 297:1694705. doi: 10.1002/ar.22974

71. Malicdan MCV, Noguchi S, Hayashi YK, Nonaka I, Nishino I. Prophylactic treatment with sialic acid metabolites precludes the development of the myopathic phenotype in the DMRV-hIBM mouse model. Nat Med. (2009) 15:690-5. doi: 10.1038/nm.1956

72. Szabó TG, Palotai R, Antal P, Tokatly I, Tóthfalusi L, Lund O, et al. Critical role of glycosylation in determining the length and structure of $\mathrm{T}$ cell epitopes. Immunome Res. (2009) 5:4. doi: 10.1186/1745-7 580-5-4 
73. van Kooyk Y, Rabinovich GA. Protein-glycan interactions in the control of innate and adaptive immune responses. Nat Immunol. (2008) 9:593-601. doi: 10.1038/ni.f.203

74. Diana J, Moura IC, Vaugier C, Gestin A, Tissandie E, Beaudoin L, et al. Secretory IgA induces tolerogenic dendritic cells through SIGNR1 dampening autoimmunity in mice. J Immunol. (2013) 191:2335-43. doi: 10.4049/jimmunol.1300864

75. Ilarregui JM, Croci DO, Bianco GA, Toscano MA, Salatino M, Vermeulen $\mathrm{ME}$, et al. Tolerogenic signals delivered by dendritic cells to $\mathrm{T}$ cells through a galectin-1-driven immunoregulatory circuit involving interleukin 27 and interleukin 10. Nat Immunol. (2009) 10:981-91. doi: 10.1038/ni.1772

76. Toscano MA, Bianco GA, Ilarregui JM, Croci DO, Correale J, Hernandez JD, et al. Differential glycosylation of TH1, TH2 and TH-17 effector cells selectively regulates susceptibility to cell death. Nat Immunol. (2007) 8:82534. doi: $10.1038 /$ ni1482

77. Clemente T, Vieira NJ, Cerliani JP, Adrain C, Luthi A, Dominguez MR, et al. Proteomic and functional analysis identifies galectin-1 as a novel regulatory component of the cytotoxic granule machinery. Cell Death Dis. (2017) 8:e3176. doi: 10.1038/cddis.2017.506

78. Orlacchio A, Sarchielli P, Gallai V, Datti A, Saccardi C, Palmerini CA. Activity levels of a beta1,6 N-acetylglucosaminyltransferase in lymphomonocytes from multiple sclerosis patients. J Neurol Sci. (1997) 151:177-83. doi: 10.1016/S0022-510X(97)00117-2

79. Brynedal B, Wojcik J, Esposito F, Debailleul V, Yaouanq J, MartinelliBoneschi F, et al. MGAT5 alters the severity of multiple sclerosis. J Neuroimmunol. (2010) 220:120-4. doi: 10.1016/j.jneuroim.2010.01.003

80. Mkhikian H, Grigorian A, Li CF, Chen HL, Newton B, Zhou RW, et al. Genetics and the environment converge to dysregulate N-glycosylation in multiple sclerosis. Nat Commun. (2011) 2:334. doi: 10.1038/ncomms1333

81. Grigorian A, Mkhikian H, Li CF, Newton BL, Zhou RW, Demetriou M. Pathogenesis of multiple sclerosis via environmental and genetic dysregulation of N-glycosylation. Semin Immunopathol. (2012) 34:415-24. doi: 10.1007/s00281-012-0307-y

82. Li CF, Zhou RW, Mkhikian H, Newton BL, Yu Z, Demetriou M. Hypomorphic MGAT5 polymorphisms promote multiple sclerosis cooperatively with MGAT1 and interleukin-2 and 7 receptor variants. J Neuroimmunol. (2013) 256:71-6. doi: 10.1016/j.jneuroim.2012.12.008

83. Dias AM, Dourado J, Lago P, Cabral J, Marcos-Pinto R, Salgueiro P, et al. Dysregulation of $\mathrm{T}$ cell receptor N-glycosylation: a molecular mechanism involved in ulcerative colitis. Hum Mol Genet. (2014) 23:241627. doi: $10.1093 / \mathrm{hmg} / \mathrm{ddt} 632$

84. Pereira MS, Maia L, Azevedo LF, Campos S, Carvalho S, Dias $\mathrm{AM}$, et al. A [Glyco]biomarker that predicts failure to standard therapy in ulcerative colitis patients. J Crohns Colitis (2018). doi: 10.1093/ecco-jcc/jjy139. [Epub ahead of print].

85. Grigorian A, Araujo L, Naidu NN, Place DJ, Choudhury B, Demetriou M. $\mathrm{N}$-Acetylglucosamine Inhibits T-helper 1 (Th1)/T-helper 17 (Th17) cell responses and treats experimental autoimmune encephalomyelitis. J Biol Chem. (2011) 286:40133-41. doi: 10.1074/jbc.M111.277814

86. McMorran BJ, Miceli MC, Baum LG. Lectin-binding characterizes the healthy human skeletal muscle glycophenotype and identifies diseasespecific changes in dystrophic muscle. Glycobiology (2017) 27:1134-43. doi: $10.1093 /$ glycob/cwx073

87. Balasubramanian M, Johnson DS, DDD Study. MAN1B-CDG: Novel variants with a distinct phenotype and review of literature. Eur J Med Genet. (2018). doi: 10.1016/j.ejmg.2018.06.011. [Epub ahead of print].

88. Wiendl H, Hohlfeld R, Kieseier BC. Immunobiology of muscle: advances in understanding an immunological microenvironment. Trends Immunol. (2005) 26:373-80. doi: 10.1016/j.it.2005.05.003

89. Afzali AM, Müntefering T, Wiendl H, Meuth SG, Ruck T. Skeletal muscle cells actively shape (auto)immune responses. Autoimmun Rev. (2018) 17:518-29. doi: 10.1016/j.autrev.2017.12.005

90. RodrÍguez E, Schetters STT, van Kooyk Y. The tumour glyco-code as a novel immune checkpoint for immunotherapy. Nat Rev Immunol. (2018) 18:204-11. doi: 10.1038/nri.2018.3

91. Blank C, Mackensen A. Contribution of the PD-L1/PD-1 pathway to T-cell exhaustion: an update on implications for chronic infections and tumor evasion. Cancer Immunol Immunother. (2007) 56:739-45. doi: 10.1007/s00262-006-0272-1

92. Okada M, Chikuma S, Kondo T, Hibino S, Machiyama H, Yokosuka T, et al. Blockage of core Fucosylation reduces cell-surface expression of PD1 and promotes anti-tumor immune responses of T cells. Cell Rep. (2017) 20:1017-28. doi: 10.1016/j.celrep.2017.07.027

93. Li CW, Lim SO, Xia W, Lee HH, Chan LC, Kuo CW, et al. Glycosylation and stabilization of programmed death ligand-1 suppresses T-cell activity. Nat Commun. (2016) 7:12632. doi: 10.1038/ncomms12632

94. Li CW, Lim SO, Chung EM, Kim YS, Park AH, Yao J, et al. Eradication of triple-negative breast cancer cells by targeting Glycosylated PD-L1. Cancer Cell. (2018) 33:187-201.e10. doi: 10.1016/j.ccell.2018.01.009

95. Cabral J, Hanley SA, Gerlach JQ, O’Leary N, Cunningham S, Ritter T, et al. Distinctive surface Glycosylation patterns associated with mouse and human CD4+ regulatory $\mathrm{T}$ cells and their suppressive function. Front Immunol. (2017) 8:987. doi: 10.3389/fimmu.2017.00987

96. Dennis JW, Lau KS, Demetriou M, Nabi IR. Adaptive regulation at the cell surface by N-glycosylation. Traffic (2009) 10:1569-78. doi: 10.1111/j.1600-0854.2009.00981.x

97. Pinho SS, Reis CA. Glycosylation in cancer: mechanisms and clinical implications. Nat Rev Cancer (2015) 15:540-55. doi: 10.1038/nrc3982

98. Rodrigues JG, Balmaña M, Macedo JA, Poças J, Fernandes Â, De-FreitasJunior JCM, et al. Glycosylation in cancer: selected roles in tumour progression, immune modulation and metastasis. Cell Immunol. (2018). doi: 10.1016/j.cellimm.2018.03.007. [Epub ahead of print].

99. van Liempt E, Bank CMC, Mehta P, Garci'a-Vallejo JJ, Kawar ZS, Geyer R, et al. Specificity of DC-SIGN for mannose- and fucose-containing glycans. FEBS Lett. (2006) 580:6123-31. doi: 10.1016/j.febslet.2006.10.009

100. van Gisbergen KPJM, Aarnoudse CA, Meijer GA, Geijtenbeek TBH, van Kooyk Y. Dendritic cells recognize tumor-specific glycosylation of carcinoembryonic antigen on colorectal cancer cells through dendritic cellspecific intercellular adhesion molecule-3-grabbing nonintegrin. Cancer Res. (2005) 65:5935-44. doi: 10.1158/0008-5472.CAN-04-4140

101. Gringhuis SI, Kaptein TM, Wevers BA, van der Vlist M, Klaver EJ, van Die $\mathrm{I}$, et al. Fucose-based PAMPs prime dendritic cells for follicular $\mathrm{T}$ helper cell polarization via DC-SIGN-dependent IL-27 production. Nat Commun. (2014) 5:5074. doi: 10.1038/ncomms6074

102. García-Vallejo JJ, Ilarregui JM, Kalay H, Chamorro S, Koning N, Unger WW, et al. CNS myelin induces regulatory functions of DC-SIGN-expressing, antigen-presenting cells via cognate interaction with MOG. J Exp Med. (2014) 211:1465-83. doi: 10.1084/jem.20122192

103. Unger WWJ, van Beelen AJ, Bruijns SC, Joshi M, Fehres CM, van Bloois L, et al. Glycan-modified liposomes boost CD4+ and CD8+ T-cell responses by targeting DC-SIGN on dendritic cells. J Control Release (2012) 160:88-95. doi: 10.1016/j.jconrel.2012.02.007

104. van Vliet SJ, Bay S, Vuist IM, Kalay H, García-Vallejo JJ, Leclerc C, et al. MGL signaling augments TLR2-mediated responses for enhanced IL-10 and TNF- $\alpha$ secretion. J Leukoc Biol. (2013) 94:315-23. doi: 10.1189/jlb.1012520

105. van Vliet SJ, Gringhuis SI, Geijtenbeek TBH, van Kooyk Y. Regulation of effector T cells by antigen-presenting cells via interaction of the C-type lectin MGL with CD45. Nat Immunol. (2006) 7:1200-8. doi: 10.1038/ni1390

106. Ruffell B, Chang-Strachan D, Chan V, Rosenbusch A, Ho CMT, Pryer $\mathrm{N}$, et al. Macrophage IL-10 blocks CD8 $+\mathrm{T}$ cell-dependent responses to chemotherapy by suppressing IL-12 expression in intratumoral dendritic cells. Cancer Cell (2014) 26:623-37. doi: 10.1016/j.ccell.2014.09.006

107. Smith LK, Boukhaled GM, Condotta SA, Mazouz S, Guthmiller JJ, Vijay R, et al. Interleukin-10 directly inhibits CD8 $(+) \mathrm{T}$ cell function by enhancing NGlycan branching to decrease antigen sensitivity. Immunity (2018) 48:299312 e5. doi: 10.1016/j.immuni.2018.01.006

108. Perdicchio M, Ilarregui JM, Verstege MI, Cornelissen LAM, Schetters STT, Engels S, et al. Sialic acid-modified antigens impose tolerance via inhibition of T-cell proliferation and de novo induction of regulatory T cells. Proc Natl Acad Sci USA. (2016) 113:3329-34. doi: 10.1073/pnas.1507706113

109. Perdicchio M, Cornelissen LAM, Streng-Ouwehand I, Engels S, Verstege MI, Boon L, et al. Tumor sialylation impedes T cell mediated anti-tumor responses while promoting tumor associated-regulatory T cells. Oncotarget (2016) 7:8771-82. doi: 10.18632/oncotarget.6822 
110. Beatson R, Tajadura-Ortega V, Achkova D, Picco G, Tsourouktsoglou TD, Klausing S, et al. The mucin MUC1 modulates the tumor immunological microenvironment through engagement of the lectin Siglec-9. Nat Immunol. (2016) 17:1273-81. doi: 10.1038/ni.3552

111. Carrascal MA, Severino PF, Guadalupe Cabral M, Silva M, Ferreira JA, Calais F, et al. Sialyl Tn-expressing bladder cancer cells induce a tolerogenic phenotype in innate and adaptive immune cells. Mol Oncol. (2014) 8:753-65. doi: 10.1016/j.molonc.2014.02.008

112. Julien S, Videira PA, Delannoy P. Sialyl-tn in cancer: (how) did we miss the target? Biomolecules (2012):435-66. doi: 10.3390/biom2040435

113. Stanczak MA, Siddiqui SS, Trefny MP, Thommen DS, Boligan KF, von Gunten S, et al. Self-associated molecular patterns mediate cancer immune evasion by engaging Siglecs on T cells. J Clin Invest. (2018) 128:4912-23. doi: 10.1172/JCI120612

114. Garín MI, Chu C-C, Golshayan D, Cernuda-Morollón E, Wait R, Lechler RI. Galectin-1: a key effector of regulation mediated by CD4+CD25+ T cells. Blood (2007) 109:2058-65. doi: 10.1182/blood-2006-04-016451

115. Stillman BN, Hsu DK, Pang M, Brewer CF, Johnson P, Liu F-T, et al. Galectin3 and galectin- 1 bind distinct cell surface glycoprotein receptors to induce $\mathrm{T}$ cell death. J Immunol. (2006) 176:778-89. doi: 10.4049/jimmunol.176.2.778

116. Matarrese P, Tinari A, Mormone E, Bianco GA, Toscano MA, Ascione B, et al. Galectin-1 sensitizes resting human T lymphocytes to Fas (CD95)mediated cell death via mitochondrial hyperpolarization, budding, and fission. J Biol Chem. (2005) 280:6969-85. doi: 10.1074/jbc.M409752200

117. Rabinovich GA, van Kooyk Y, Cobb BA. Glycobiology of immune responses. Ann N Y Acad Sci. (2012) 1253:1-15. doi: 10.1111/j.1749-6632.2012.06492.x

118. Yang RY, Hsu DK, Liu FT. Expression of galectin-3 modulates T-cell growth and apoptosis. Proc Natl Acad Sci USA. (1996) 93:6737-42. doi: 10.1073/pnas.93.13.6737

119. Lau KS, Partridge EA, Grigorian A, Silvescu CI, Reinhold VN, Demetriou $\mathrm{M}$, et al. Complex N-glycan number and degree of branching cooperate to regulate cell proliferation and differentiation. Cell (2007) 129:123-34. doi: 10.1016/j.cell.2007.01.049

120. Kouo T, Huang L, Pucsek AB, Cao M, Solt S, Armstrong T, et al. Galectin-3 shapes antitumor immune responses by suppressing CD8+ T cells via LAG3 and inhibiting expansion of Plasmacytoid dendritic cells. Cancer Immunol Res. (2015) 3:412-23. doi: 10.1158/2326-6066.CIR-14-0150

121. Zhu C, Anderson AC, Schubart A, Xiong H, Imitola J, Khoury SJ, et al. The Tim-3 ligand galectin- 9 negatively regulates T helper type 1 immunity. Nat Immunol. (2005) 6:1245-52. doi: 10.1038/ni1271

122. Oomizu S, Arikawa T, Niki T, Kadowaki T, Ueno M, Nishi N, et al. Galectin-9 suppresses Th17 cell development in an IL-2-dependent but Tim-3-independent manner. Clin Immunol. (2012) 143:51-8. doi: 10.1016/j.clim.2012.01.004

123. Kang CW, Dutta A, Chang LY, Mahalingam J, Lin YC, Chiang JM, et al. Apoptosis of tumor infiltrating effector TIM-3+CD8 $+\mathrm{T}$ cells in colon cancer. Sci Rep. (2015) 5:15659. doi: 10.1038/srep15659

124. Su EW, Bi S, Kane LP. Galectin-9 regulates $\mathrm{T}$ helper cell function independently of Tim-3. Glycobiology (2011) 21:1258-65. doi: $10.1093 /$ glycob/cwq214
125. Almeida L, Lochner M, Berod L, Sparwasser T. Metabolic pathways in T cell activation and lineage differentiation. Semin Immunol. (2016) 28:514-24. doi: 10.1016/j.smim.2016.10.009

126. Wang T, Marquardt C, Foker J. Aerobic glycolysis during lymphocyte proliferation. Nature (1976) 261:702-5. doi: 10.1038/261702a0

127. Wang R, Green DR. Metabolic checkpoints in activated T cells. Nat Immunol. (2012) 13:907-15. doi: 10.1038/ni.2386

128. Wellen KE, Thompson CB. A two-way street: reciprocal regulation of metabolism and signalling. Nat Rev Mol Cell Biol. (2012) 13:270-6. doi: $10.1038 / \mathrm{nrm} 3305$

129. Abdel Rahman AM, Ryczko M, Pawling J, Dennis JW. Probing the hexosamine biosynthetic pathway in human tumor cells by multitargeted tandem mass spectrometry. ACS Chem Biol. (2013) 8:2053-62. doi: 10.1021/cb4004173

130. Grigorian A, Lee SU, Tian W, Chen IJ, Gao G, Mendelsohn R, et al. Control of T cell-mediated autoimmunity by metabolite flux to $\mathrm{N}$-glycan biosynthesis. $J$ Biol Chem. (2007) 282:20027-35. doi: 10.1074/jbc.M701890200

131. Love DC, Hanover JA. The hexosamine signaling pathway: deciphering the "O-GlcNAc code". Sci STKE (2005) 2005:re13. doi: 10.1126/stke.3122005re13

132. Kreppel LK, Hart GW. Regulation of a cytosolic and nuclear O-GlcNAc transferase. Role of the tetratricopeptide repeats. J Biol Chem. (1999) 274:32015-22. doi: 10.1074/jbc.274.45.32015

133. Sasai K, Ikeda $Y$, Fujii $T$, Tsuda $T$, Taniguchi N. UDP-GlcNAc concentration is an important factor in the biosynthesis of beta1,6branched oligosaccharides: regulation based on the kinetic properties of N-acetylglucosaminyltransferase V. Glycobiology (2002) 12:119-27. doi: 10.1093/glycob/12.2.119

134. Ryczko MC, Pawling J, Chen R, Abdel Rahman AM, Yau K, Copeland JK, et al. Metabolic reprogramming by hexosamine biosynthetic and golgi NGlycan branching pathways. Sci Rep. (2016) 6:23043. doi: 10.1038/srep23043

135. Chien MW, Lin MH, Huang SH, Fu SH, Hsu CY, Yen BLJ, et al. Glucosamine modulates $\mathrm{T}$ cell differentiation through down-regulating N-linked Glycosylation of CD25. J Biol Chem. (2015) 290:29329-44. doi: 10.1074/jbc.M115.674671

136. Zhang GX, Yu S, Gran B, Rostami A. Glucosamine abrogates the acute phase of experimental autoimmune encephalomyelitis by induction of Th2 response. J Immunol. (2005) 175:7202-8. doi: 10.4049/jimmunol.175. 11.7202

Conflict of Interest Statement: The authors declare that the research was conducted in the absence of any commercial or financial relationships that could be construed as a potential conflict of interest.

Copyright (C) 2018 Pereira, Alves, Vicente, Campar, Silva, Padrão, Pinto, Fernandes, Dias and Pinho. This is an open-access article distributed under the terms of the Creative Commons Attribution License (CC BY). The use, distribution or reproduction in other forums is permitted, provided the original author(s) and the copyright owner(s) are credited and that the original publication in this journal is cited, in accordance with accepted academic practice. No use, distribution or reproduction is permitted which does not comply with these terms. 